\title{
Faktor yang Mempengaruhi Kinerja Bidan dalam Asuhan Perawatan Metode Kanguru pada Ibu BBLR
}

\author{
Naluri Widyaningsih Syamsiedi*, Martha Irene Kartasurya**, Sri Achadi Nugraheni** \\ *Dinas Kesehatan Kabupaten Banyumas, \\ **Fakultas Kesehatan Masyarakat, Universitas Diponegoro \\ Email: nalurisyamsiedi@gmail.com
}

\begin{abstract}
Low Birth Weight $(L B W)$ is one of the causes of InfantMortality Rate in Indonesia. One of the efforts to save $L B W$ baby from death is Kangaroo Mother Care $(K M C)$. The implementation of KMC in Banyumas was not yet optimal. The purpose of this study was to analyze some factors related to the performance of midwives in providing KMC to the mothers of LBW babies.

This study used quantitative approach with 80 respondents who were selected using clustered random sampling. Data collection was conducted through interviews. Data were analyzed by rank spearman correlation and logistic regression method.
\end{abstract}

The results showed that $41.2 \%$ of the subjects had low performance in KMC treatment. Among the subjects, 36.2\% had low knowledge, $45.0 \%$ had low perception, $50.0 \%$ had low motivation, $45.0 \%$ had low attitude, $47.5 \%$ had low supervision and $46.3 \%$ had low leadership. There was a positive correlation between knowledge and midwife performance in KMC ( $r=$ $0.37 ; p=0.001)$. Midwifes with good knowledge had 5 times better performance in providing KMC than the midwifes with low knowledge $(\operatorname{Exp}(B)=5,021)$. Perceptions, motivations, attitudes, supervision and leadership had no relation to the performance of midwives in KMC.
It is recommended to the Public Health Office to increase midwifes' knowledge and performance on KMC and use reward and punishment method.

Keywords: Low Birth Weight, Kangaroo Mother Care, Midwife's performance.

\section{PENDAHULUAN}

Salah satu penyebab tingginya AKB di Indonesia adalah bayi lahir berat rendah (BBLR). Perawatan metode kanguru (PMK) merupakan salah satu upaya untuk menyelamatkan BBLR dari kematian.. BBLR memiliki resiko yang lebih besar untuk mengalami masalah kesehatan. ${ }^{1}$

Di Indonesia angka kejadian BBLR masih cukup tinggi. Data Riskesdas tahun 2013 menunjukan angka kejadian BBLR di Indonesia mencapai $10,2 \% .^{2}$ Di Propinsi Jawa Tengah pada tahun 2014 kasus BBLR mencapai3,9\% ${ }^{3}$ dan di Kabupaten Banyumas tahun 2016 mencapai 1533 kasus atau 5,39\%. ${ }^{4}$

Perawatan Metode Kanguru (PMK) merupakan salah satu upaya pencegahan hipotermi pada BBLR. Prinsipskin to skin contact yaitu perpindahan panas secara konduksi dari ibu ke bayi sehingga bayi tetap hangat. Suhu tubuh ibu merupakan sumber panas yang efisien dan murah, yang dapat memberikan lingkungan hangat pada bayi dan juga meningkatkan hubungan ibu dengan bayinya. ${ }^{5}$ 
Pelaksanaan PMK memerlukan tenaga kesehatan profesional yang memiliki pengetahuan dan pengalaman serta keterampilan yang baik.Permenkes Nomor 369/Menkes/SK/III/2007 tentang standar profesi bidan menunjukan bahwa salah satu kompetensi yang harus di miliki oleh seorang bidan adalah memberikan asuhan yang bermutu tinggi, komprehensif pada bayi baru lahir sampai dengan umur 1 bulan serta penanganan neonatus beresiko, khususnya BBLR. Salah satu asuhan yang diberikan bidan kepada BBLR adalah asuhan perawatan metode kangguru. ${ }^{6}$

Berdasarkan hasil studi pendahuluan kepada 20 orang ibu BBLR dan 10 orang bidan di kabupaten Banyumas, didapatkan bahwa $80 \%$ ibu tidak diperkenalkan dengan baju kanguru dan $60 \%$ ibu tidak mendapatkan konseling tentang penerapkan PMK secara menyeluruh. Pelaksanaan PMK oleh bidan kepada ibu dengan BBLR tidak rutin dilakukan (50\%), tidak menggunakan baju kanguru yang telah tersedia (70\%), tidak melakukan konseling kepada ibu dan keluarga (50\%).

Penelitian ini bertujuan untuk mengetahui faktor - faktor yang mempengaruhi kinerja bidan dalam memberikan asuhan perawatan metode kanguru pada ibu bayi BBLR di Kabupaten Banyumas.

\section{METODE PENELITIAN}

Penelitian ini merupakan penelitian kuantitatif dengan pendekatan waktu potong lintang (cross sectional). Pengumpulan data primer menggunakan kuesioner terstruktur. Populasi dalam penelitian ini adalah seluruh bidan yang bekerja di puskesmas mampu salin di Kabupaten Banyumas yang pernah menolong bayi BBLR sebanyak 393 orang. Subjek pada penelitian ini sebanyak 80 orang, pengambilan sampeldilakukan dengan metode clustered random sampling, Analisis data penelitian dengan menggunakankorelasi rank spearman dan regresi logistik.

\section{HASIL DAN PEMBAHASAN}

Rerata umur responden adalah 41 tahun dengan standar deviasi sebesar 5,9 tahun. Sebanyak $83,8 \%$ responden memiliki tingkat pendidikan D-III kebidanan dengan rerata masa kerja 19 tahun dengan standar deviasi 6,7 tahun.

Kinerja bidan dalam asuhan PMKmasih kurang pada 42,2\%. Kinerja kurang dalam hal ini adalah bidan tidak melaksanakan PMKsesuai dengan SOP.Distribusi jawaban responden terkait kinerja pada pelaksanaan asuhan PMK pada ibu dengan bayi BBLR dapat dilihat pada Tabel 1.

Pengetahuan bidan dalam asuhan PMK masih kurang pada36,2\%. Pengetahuan bidan masih kurang padaciri Bayi Berat Badan Lahir Moderat, Bayi Berat Badan Lahir Sangat Rendah serta manfaat PMK dan $63,8 \%$ responden memiliki pengetahuan yang baik tentang manfaat PMK dan pengertian BBLR.

Persepsi bidan tentang asuhan PMK pada ibu dengan bayi BBLR masih kurang pada 45,0\%. Sebagian besar Responden setuju dengan pernyataan PMK tidak selalu dapat dilaksanakan $(58,8 \%)$.

Motivasi bidan dalam asuhan PMK masih kurang pada 50,0\%. Motivasi kurang terkait dengan bidan tidak menerapkan PMK dengan baik pada semua BBLR dan responden memiliki motivasi yang baik dalam hal membina hubungan baik dengan sejawat dalam pelaksanaan asuhan PMK.

Responden masih memiliki sikap yang kurang tentang pelaksanaan asuhan PMK pada ibu dengan bayi BBLR pada 45,0\%. Sebagian besarresponden setuju dengan pernyataan bahwa PMK dapat dilakukan tanpa bantuan bidan $(36,2 \%)$.

47,5\% responden berpendapat bahwa supervisi dalam asuhan PMK masih kurang karena supervisi tidak terjadwal dengan baik dan bikor tidak memberikan petunjuk serta masukan yang jelas terkait dengan asuhan PMK yang dilakukan bidan dan $52,5 \%$ responden berpendapat supervisi 
dalam asuhan PMK baik karena digunakan untuk menilai tugas dan kinerja bidan.

46,3\% responden berpendapat bahwa kepemimpinan dalam asuhan PMK masih kurang karena belum adanya reward dan punishment bagi bidan sesuai dengan kinerjanya dan $53,7 \%$ responden berpendapat kepemimpinan dalam asuhan PMK baik dalam hal pemberian tugas dan tanggung jawab penuh dalam pelaksanaan PMK yang diberikan kepala puskesmas.

Tabel 1. Hubungan Pengetahuan, Persepsi, Motivasi, Sikap, Supervisi dan Kepemimimpinan dengan Kinerja Bidan dalam Memberikan Asuhan PMK

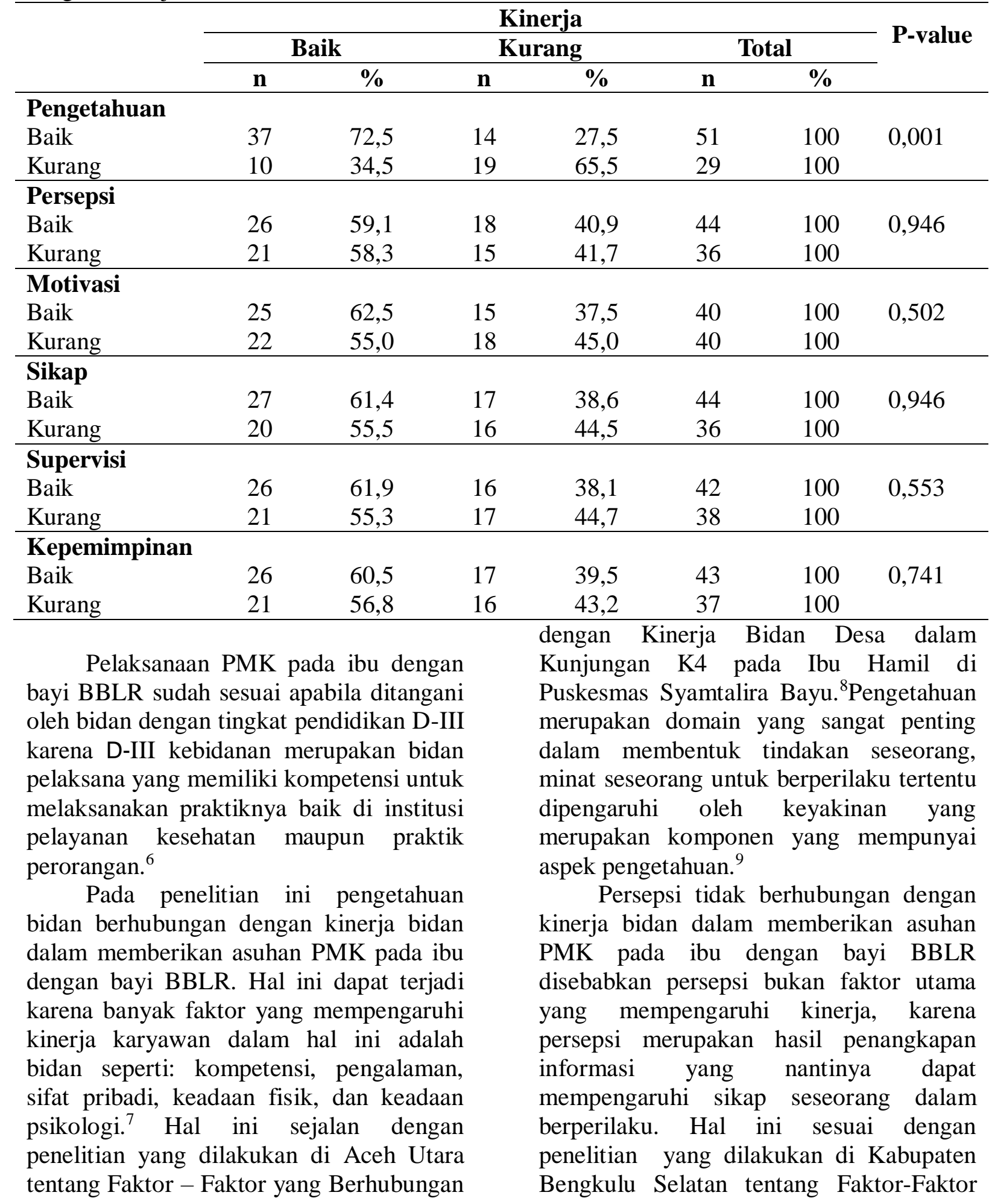


yang Mempengaruhi Kinerja Bidan dalam Deteksi Dini Resiko Tinggi Ibu Hamil pada Pelayanan Antenatalyang menyebutkan tidak ada hubungan antara persepsi dengan kinerja bidan, sedangkan faktor yang berhubungan dengan kinerja bidan adalah pengetahuan, motivasi, persepsi supervisi bidan koordinator, persepsi beban kerja, sarana prasarana dengan kinerja. ${ }^{10}$

Motivasi tidak berhubungan dengankinerja bidan dalam melakukan asuhan PMK pada ibu dengan BBLR.Hal ini sejalan dengan penelitian yang dilakukan di Kabupaten Kendaltentang Faktor-Faktor yang Mempengaruhi Kinerja Bidan Desa dalam Pelayanan Pos Kesehatan Desa (POSKESDES). ${ }^{11} \mathrm{Hal}$ ini tidak sesuai dengan teori Gibson yang menyebutkan bahwa motivasi berkaitan dengan tingkat usaha seseorang dalam mencapai suatu tujuan dan motivasi berkaitan erat dengan kinerja dan kepuasan kerja. $^{12}$

Motivasi merupakan akibat dari hasil yang ingin dicapai oleh seseorang dan perkiraan bahwa tindakan yang dilakukan akan mengarah pada hasil yang diinginkannya. Jika seseorang menginginkan sesuatu dan harapan untuk memperoleh sesuatu cukup besar maka seseorang tersebut akan terdorong untuk mendapatkan hal yang diinginkannya. ${ }^{13}$

Sikap tidak berhubungan dengankinerja bidan dalam melakukan asuhan PMK pada ibu dengan BBLR.Sikap dibentuk melalui proses belajar sosial yang sebagian diperoleh dari orang lain. Hal ini sejalan dengan penelitian yang dilakukan di Kota Pekanbaru tentang Kinerja Bidan dalam Mendukung Program Imunisasi Menyusu Dini (IMD). ${ }^{14}$ Hasil penelitian ini tidak sejalan dengan teori yang dikemukakan oleh Gibson, yang menyatakan sikap merupakan faktor penentu perilaku karena berhubungan dengan persepsi, kepribadian dan motivasi. Sikap selalu berhubungan dengan komponen emosional, kognitif, dan perilaku. Hal ini berarti bidan akan bersikap dan bekerja dengan baik apabila telah memiliki ketiga komponen tersebut. ${ }^{12}$ Supervisi tidak berhubungan dengankinerja bidan dalam melakukan asuhan PMK pada ibu dengan BBLR.Hal ini sejalan dengan penelitian yang dilakukan di Kota Semarang tentang Analisi Kinerja Mahasiswa Program DIII Kebidanan dalam Pendampingan Ibu Hamil Risti. ${ }^{15}$ Muninjaya berpendapat bahwa supervisi merupakan salah satu bagian proses atau kegiatan dari fungsi pengawasan dan pengendalian (controlling). ${ }^{16}$ Dengan demikian apabila supervisi dilakukan dengan baik maka akan diperoleh banyak manfaat diantaranya adalah: supervisi dapat meningkatkan pengetahuan dan keterampilan bawahan serta makin terbinanya hubungan dengan suasana kerja yang lebih harmonis antara atasan dengan bawahan. Selain itu supervisi juga dapat meningkatkan efisiensi kerja, hal ini erat hubungannya dengan makin rendahnya kesalahan yang dilakukan oleh karyawan. ${ }^{17}$

Kepemimpinan tidak berhubungan dengankinerja bidan dalam melakukan asuhan PMK pada ibu dengan BBLR . Hal ini sejalan dengan penelitian di Kabupaten Gresik tentang Faktor-Faktor yang Berpengaruh terhadap Kinerja Bidan dalam Pelaksanaan Standar Asuhan Kebidanan Antenatal Carebahwa kepemimpinan tidak berhubungan dengan kinerja bidan dalam pelaksanaan standar asuhan kebidanan ANC. ${ }^{18}$

Dalam suatu manajemen organisasi, kepemimpinan berarti kemampuan untuk mengendalikan organisasi melalui perencanaan, pengorganisasian, penggerakan, pengawasan dalam rangka mencapai tujuan. Rendahnya pemeliharaan dan perhatian kepada bidan bisa menyebabkan penurunan semangat kerja, cepat bosan serta lamban menyelesaikan tugas, sehingga dapat menyebabkan penurunan prestasi kerja bidan dalam melaksanakan asuhan PMK pada ibu dengan bayi BBLR. ${ }^{19}$ 
Menurut Notoatmodjo bahwa pengetahuan merupakan domain yang sangat penting dalam terbentuknya perilaku seseorang. Apabila perilaku didasari oleh pengetahuan, kesadaran dan sikap yang positif, maka perilaku tersebut akan bersifat langgeng (long lasting). ${ }^{15}$ Berdasarkan teori Kinerja (job performance) tercakup sejumlah hasil, yaitu hasil obyektif dan hasil perilaku pribadi. Hasil objektif berupa kuantitas dan kualitas keluaran sesuai dengan tugas dan standar masing-masing pemegang pekerjaan. Hasil perilaku pribadi berupa reaksi terhadap pekerjaan: hadir secara teratur atau mangkir, tetap bekerja atau berhenti. Lebih lanjut masalah fisiologi dan psikologi dapat menjadi konsekuensi kinerja. Berdasarkan teori tersebut dapat disimpulkan bahwa pengetahuan dapat mempengaruhi kinerja bidan dalam memberikan asuhan PMK pada ibu dengan bayi BBLR. ${ }^{20}$

\section{KESIMPULAN}

Kinerja Bidan dalam melaksanakan Asuhan PMK pada Ibu BBLR di Kabupaten Banyumas berhubungan dengan pengetahuan bidan tentang PMK. Perlu peningkatan pengetahuan dan kemampuan bidan melalui pembinaan, seminar atau pelatihan terkait dengan BBLR, Manfaat pelaksanaan PMK dan cara melakukan PMK. Selain itu juga perlu menerapkan sistemreward dan punisment terkait kinerja bidan dalam tugas, pokok dan fungsinya.

\section{UCAPAN TERIMA KASIH}

Penulis mengucapkan terima kasih kepada Dinas Kesehatan Kabupaten Banyumas dan Puskesmas di seluruh Kabupaten Puskesmas atas ijin yang diberikan untuk melaksanakan penelitian. Penulis juga berterima kasih kepada seluruh bidan yang telah bersedia berpartisipasi dalam penelitian ini.

\section{DAFTAR PUSTAKA}

1. Manuba, IAC, dkk. Ilmu Kebidanan, Penyakit Kandungan dan KB Untuk
Pendidikan Bidan. Jakarta: EGC; 2005.

2. Dinas Kesehatan Provinsi Jawa Tengah. Profil Kesehatan Provinsi Jawa Tengah Tahun 2015. Semarang: 2015.

3. Dinas Kesehatan Kabupaten Banyumas. Data Profil Kesehatan Kabupaten Banyumas tahun 2016. Purwokerto: 2016.

4. Departemen Kesehatan Republik Indonesia. Sistem Kesehatan Nasional. 2009.

5. Angriani S, dkk. Hubungan Antara Metode Kanggaroo Mother Care (KMC) terhadap Suhu Tubuh BBLR di RSKD Ibu dan Anak Pertiwi Makasar. Jurnal Ilmu Kesehatan Diagnosis: 2014. Vol.4.

6. Depkes RI. Keputusan Menteri Kesehatan Republik Indonesia nomor 369/Menkes/SK/III/2007 Tentang Standar Profesi Bidan. Jakarta: Depkes RI; 2008.

7. Ilyas, Y.Kinerja, Teori, Penilaian, dan Penelitian. Depok: Pusat Kajian Ekonomi Kesehatan FKM UI;2001.

8. Kusmayati, L. Faktor-Faktor yang Berhubungan dengan Kinerja Bidan Desa dalam Kunjungan K4 pada Ibu Hamil di Puskesmas Syamtalira Bayu Kabupaten Aceh Utara Tahun 2012. Jurnal Kesehatan Masyarakat: 2012.

9. Notoatmodjo, S. Metodologi Penelitian Kesehatan. Jakarta: Rineka Cipta; 2002.

10. Yunita, H. Faktor-Faktor yang Mempengaruhi Kinerja Bidan dalam Deteksi Dini Resiko Tinggi Ibu Hamil pada Pelayanan Antenatal di Kabupaten Bengkulu Selatan. Semarang: Magister Ilmu Kesehatan Masyarakat, Undip; 2013.

11. Mariyana, W. Faktor-Faktor yang Mempengaruhi Kinerja Bidan Desa dalam Pelayanan Pos Kesehatan Desa (POSKEDES) di Wilayah Kabupaten Kendal. (Tesis). Semarang: Magister Ilmu Kesehatan Masyarakat, Undip; 2016. 
12. Gibson JL, Ivancevich JM, Donnelly JH. Organisasi Perilaku Struktur Proses. Edisi 8, Jilid 2. Jakarta: Bina Rupa Aksara; 2010

13. Vroom VH. Work and Motivation. New York: John Willey \& Son, Inc; 1964.

14. Mardiah., Lipoeto, Nur.I., Nursal, Dien. Kinerja Bidan dalam Mendukung Program Imunisasi Menyusu Dini (IMD) di Kota Pekanbaru. Jurnal Kesehatan Masyarakat: 2010. 6 (2).

15. Adespin, DA. Analisis Kinerja Mahasiswa Program DIII Kebidanan dalam Pendampingan Ibu Hamil Risti di Kota Semarang. (Tesis). Semarang: Magister Ilmu Kesehatan Masyarakat, Undip; 2015.

16. Muninjaya, A. Manajemen Kesehatan. Jakarta: EGC; 1999.

17. Suarli,YB. Manajemen Keperawatan dengan Pendekatan Praktis. Jakarta: Erlangga; 2009.

18. Hamidah, S. Faktor-Faktor yang Berpengaruh terhadap Kinerja Bidan dalam Pelaksanaan Standar Asuhan Kebidanan Antenatal Care. (Tesis). Semarang: Magister Ilmu Kesehatan Masyarakat, Undip; 2012.

19. Siagian, S. Manajemen Sumber Daya Manusia, Edisi Cetakan 8. Jakarta: Bumi Aksara; 2010.

20. Notoatmodjo, S. Promosi Kesehatan dan Ilmu Perilaku. Jakarta: Rineka Cipta; 2010. 